Historic, archived document

Do not assume content reflects current scientific knowledge, policies, or practices. 

No. 2 .

\title{
Heikes Nurseries,
}

\author{
(ESTABLISHED 18\%?.)
}

THE HEIKES NURSERIES COMPANY, - - Proprietors,

$$
\text { D) AYTON, OHIO. }
$$

OFFICE-CITY LIMITS, NORTH MAIN STREET.

The Publication of this List abrogates previous quotations.

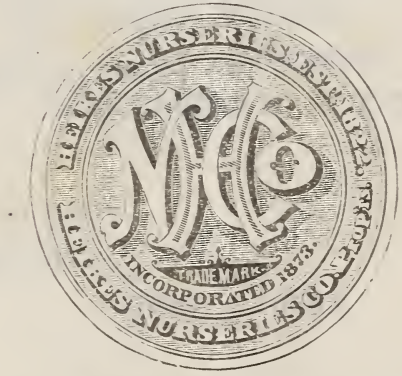

SHMI-A N N UAL TRADE LIST.

(FOR YURSERTMEN ONLY).

SPIRII G, 1874. 
OE FICE ES.

W. F. HEIRES, President. JOHN P CRAIGHEAD, secrolary.

S. D. BEAR, IRVIN C SOUDERS, Isst secretury.

liee Presedent and sup t. WM. H. GoNDERT, Accountant.

\section{DIR ECTO IS S}

W. F. HEIKLS.

S D BEAR,
JOHN P. CRAIGHEAD,

PETER BOHLENDER, HENRY A. SMITH. 


\section{NOTICE.}

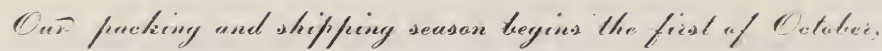

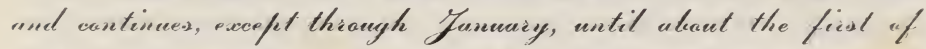
- llogyos

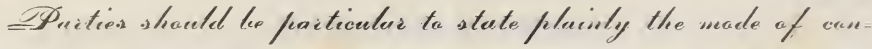

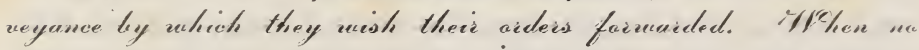

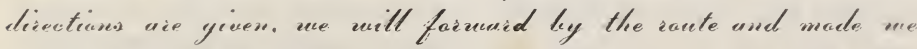

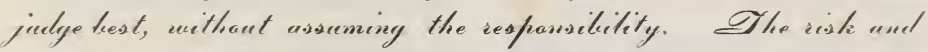

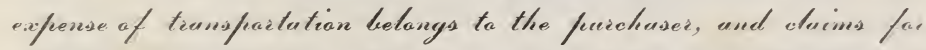

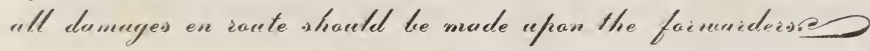

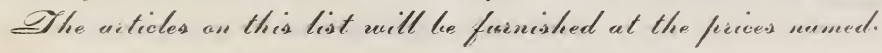

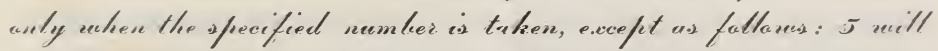
he friverished at the $I C$ intes, 50 at the $\mathrm{ICC}$ iates, ared $\mathrm{SCC}$ at

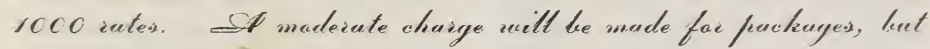

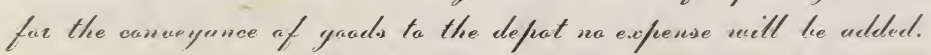

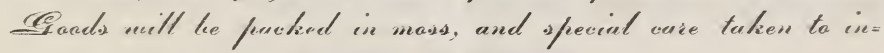

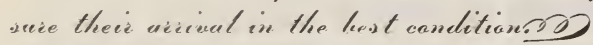

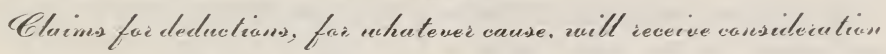

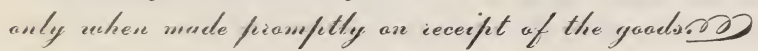

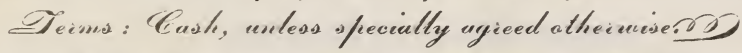

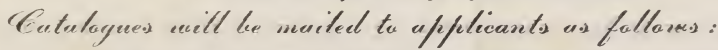

- 10. r.- Deseriftive Cutulague.

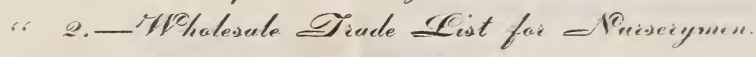

"3.- Trealeir' Epice List.

\section{The Heikes Nurseries Company.}

Daytos, O., Fieb. 1, 1873. 


\section{INDUCEMENTS.}

In the same arocation, one business house bolds adrantages in some respects over another. We heg leave to mention the following advantages claimed for this house, to which we trust our patrons will be able to bear favorable testimony.

\section{EARLY SHIPMENTS.}

The mildness of our winters allows us an almost uninterrupted season for shipments from the 1st of October to the 1st of May, the month of January usually being the only exception, consequently for the South and West especially, which requires early transportation in Spring, our location will be found a peculiarly favorable one. For the North and East also, with those who desire to re-distribute stock, the adrantages of an early opportunity for shipments cannot be estimated.

\section{PROMPT SHIPMENIS}

Our system, in which the "sets of men " who grow the stock have only to deliver it to the packing grounds to be packed by others, whose exclusive business it is, and our railroad facilities, there being no less than eight conrerging lines obriating the necessity of "waiting a day for a car," gives us an advantage for prompt shipment seldon offered. Our facilities for shipping via River, brings us into cheap and close connection with

\section{SOUTHERN POINTS.}

The distance from Dayton to Cincinnati being only 60 miles, and the connection between the two cities being made by a single line of road, the transfer to the River, where a line of boats runs daily, requires but one day.

\section{CAREAULNES IN PACKIBG.}

In this important matter we are especially careful, and pride ourselves upon the good condition of the plants thus assured upon arrival at the point of destination. During the winter.

\section{DANGER FRUM FROST}

is almost entirely obriated by the careful manner in which our goods are packed, and but a short time intervenes each season in which we cannot safely send out stock. 


\section{SUCCESTEU PROPAGATION.}

The peculiar adaptation of soil and climate in this locality to the requirements for successful propagation has proven an important auxillary to the success of this establishment. The rariety of soil being sufficient for the growth of all kinds of trees and plants in general cultivation, and the climate in its steadiness and freedom from extreme changes of temperature, renders propagation by huds, so precarious in some sections, almost a certainty bere.

\section{PROMPT COLLECTIONS.}

The strict rules of our house in regard to payment. always requiring cash with the order, approved note or satisfactory reference, has placed us in position to be able to fuifill our promises to our customers from a full stock, in a prompt and reliable business manner.

\section{EXCLUSIVELY WHOLESALE.}

It has long been our belief that the Nursery business should be dignified by the adoption of the same commercial rules which control other industries, and each year has confirmed us in this opinion more and more, until we have concluded to organize our establishment upon a basis which will allow us hereafter to confine ourselves to an exclusively wholesale business, selling only to those who buy to sell again. Under these arrangements, retail nurseries will not find themselves in competition with wholesale rates. We shall hope, through this plan, to be able to place ourselves in systematic relations with retail nurseries, who will depend on us regularly for their special supplies. Uur adrantages enable us to offer complete supplıes for nurserics of this class, it their oruers are made in good season Nurserymen, whether ordering in 'arge or small quantities, may depend upon a cheerful and promptattention to their wants. 


\section{Pur Mammoth fiellars.}

Tob able to meet the necessities for Winter and early spring shipments. we have greatly extended our collar room and comreniemese for parking. We have now the largest cellatrs for this pmpose, and the hest arranged pateking stromuls in the l'nited states.

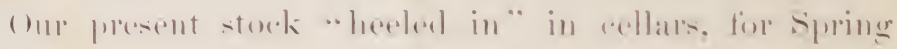

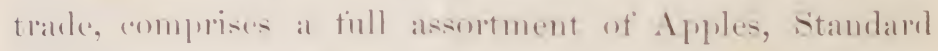
and Dwart P'alls. Peaches, Cherries, Apricots, Nectarines,

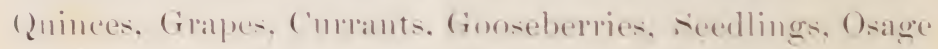

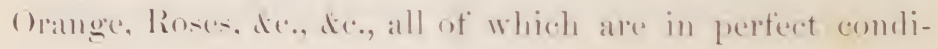
tion, and are now realy for shipment. Those who desire early and prompt shipments should send in their orders eally, to allow us the opportmity to fill them before the hurry of the season. 


\title{
SPECIALTIES.
}

\author{
Each. Per 10. Per 100 Per 1000 \\ Peaches, Crawford's Early and Late, alone, No. 1... \$ \$8 \$ \$ \$ \$ \$ $\$ 00$

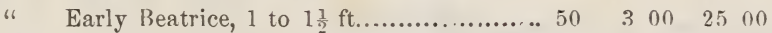

This sort was worked on young seedlings in June last, making a clean, healthy growtb the same Summer. They are well ripened and in guud condition to tramsplant

Plums, Wild Guose, 1 year, 3 to $4 \mathrm{ft}$, light......... $250 \quad 20 \quad 00$

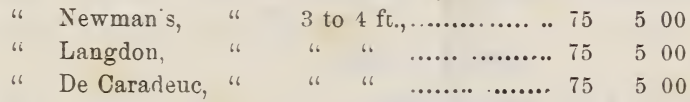

The last three are varieties of the same family as the Wild Goose, but ripening at different seasons, from earliest to latest, making an important acquisition.

Peaches, Blood-Leaved, 1 year, No. 1 .............. 35 $\begin{array}{llll}50 & 20 & 00\end{array}$

Utah Hybrid Cherries, Dwarf, 1 year, $1 \frac{1}{2}$ to $2 \mathrm{ft} \ldots . .50 \quad 400 \quad 3500$

The interest in this novelty increases each season.

Apples, Tetofski, 4 to $5 \mathrm{ft}$., No. $1 \ldots \ldots \ldots . \ldots \ldots \ldots . . . . . . . .200 \quad 200$

Gooseberries, Mountain Seedl'g, 1 yr., layers transp. $\quad \begin{array}{lllll}50 & 12 & 50\end{array}$

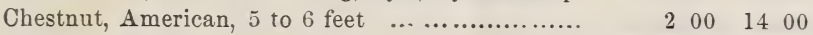

12000

Pecans, 1 year, Texas selected..................... $20 \quad 1 \quad 50 \quad 1000$

Calycanthus Seedlings, 1 year, 12 to 18 inches...... J $00 \quad 800$
"
"6
6 to 8 inches......
300
30 00

Peach Seedlings, 1 year, $3-16$ inch at collar...... per $10,000, \$ 4500 \quad 500$

A suitable size for grafting to plums or peaches, and a stock profitable to work

Peach Seedlings, light, for transplanting........... per $10,000, \$ 3500 \quad 400$

These plants are of the proper size for transplanting into nursery rows next spring to be budded to peaches Plantings made with these serdlings are more curtuin than from seeds. We have grown specially large quantities this yenr, our past experience having demonstrated their value. 


\section{FIRUT DEPARTMENT.}

1. When less than ten of $n$ variety are ordered, the price will be charged at the rate per 10 .

\section{APPLES-Standard.}

Per 10. Per 100. Per 1000: Five to seven feet, 1 st selection........................\$1 $50 \quad \$ 1250 \$ 100 \quad 00$

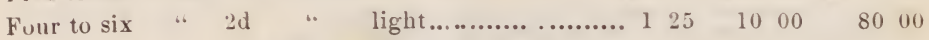
APPLES-Dwarf. (On Paradise.)

Three years, $2 !$ to + feet, 1 st selection................ 2 $00 \quad 1600 \quad 150 \quad 00$ $\begin{array}{llllllllll} & 6 & 6 & 4 & \text { Hyslop \& Transc'nd't } 2 & 50 & 20 & 00 & 175 & 00\end{array}$ APPLES-Crab.

Hewes Virginia, 3 to 4 feet, 3 and 4 years. .......... $200 \quad 1500 \quad 12500$

Transcendant, Hyslop \& Siberians, 4 to 6 ft., 2 to 3 yrs. $\quad 1500 \quad 12500$

PEARs-Standard.

Two and three years, Bartlett's, extra selected......... $600 \quad 50 \quad 00$

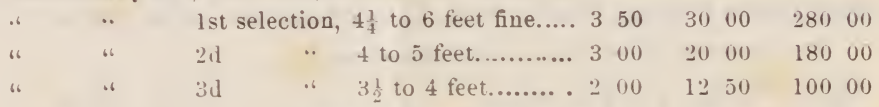

PEARS - Dwarf.

Two years, lst selection................................. $200 \quad 1800 \quad 170 \quad 00$

Three yrs, 2d .. Transplanted.................. $150 \quad 50 \quad 1250$

\section{CHERRIES-Standard.}

Hearts and Bigarreaus, one year, 4 to 6 feet........... 2 $00 \quad 1600 \quad 150 \quad 00$

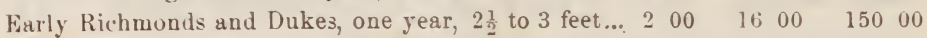

CHERRIES-Dwarf.

One year, well branched $201) \quad 1600 \quad 150 \quad 00$

PEAC riES-Standard.

One year from bud. No. 1, fine..................... 1 $100750 \quad 7000$

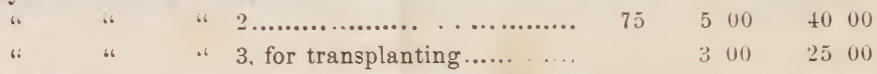

These Peaches of the third size are protitable for Transplanting into nurseries, and especially so for sections where bnds succeed indifferently.

PEACHES-Dwarf.

Golden Dwarf, $1 \frac{1}{2}$ to 2 feet. 2001600 15000 
PLUMS-Standard. (On Peach).

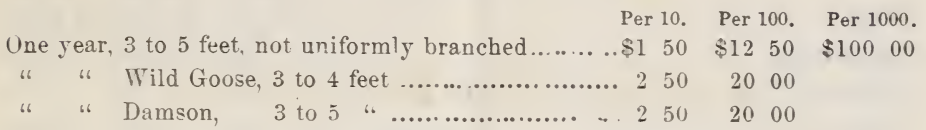

PLUMS-Dwarf. (Utah Hybrid Cherry).

One year, branched, $1 \frac{1}{2}$ to 2 feet, each 50 cts ......... 400

\section{APRICOTS.}

One year, 3 to 5 feet, very fine $250 \quad 20 \quad 00$

\section{NECTARINES.}

One year, 3 to 5 feet, very fine $150 \quad 1200$

\section{QUINCES.}

Orange, $2 \frac{1}{2}$ to 3 feet $300 \quad 2500$

\section{GRAPES.}

In Small Fruits and Seedlings, when less than one hundred of a variety are ordered, the price will be charged at the rate per ten.

Agawam, 1 year, No. 1 (Roger No. 15).................

Catawba, 1 " " $200 \quad 1500$

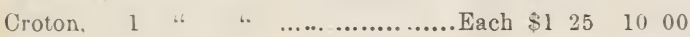

Concord 1 . 1 .

Creveling. 1 " 1 "

Delaware. 2 . " "strong layer................ 200

$75 \quad 500$

4500

Hartford Prolific, 1 year, No. $1 \ldots . . . . . . . . . . . . . . . . .1010$

$500 \quad 4500$

Ives Seedling,

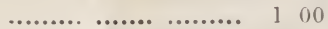

1500

Iona.

70

1600

$600 \quad 50 \quad 00$

Eumelan.

150

800

71) 00

Martba,

400

600

$50 \quad 00$

Goethe.

200

1250

$100 \quad 00$

Wilder,

Salem,

Merrimack,

$$
\text { ....................... }
$$$$
3500
$$

2500

22500

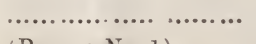

(Rogers No. 1).........

200

1600

15000

$\begin{array}{llllll}\text { " } & 4 & 4 & & & \end{array}$

1600

15000

Lindley,

6. 53 ....... 200

1600

15000

" $\quad$ " 19 ....... 200

1600

15000

" $\quad$ " 9

200

1600

15000 


\section{RASPBERRIES.}

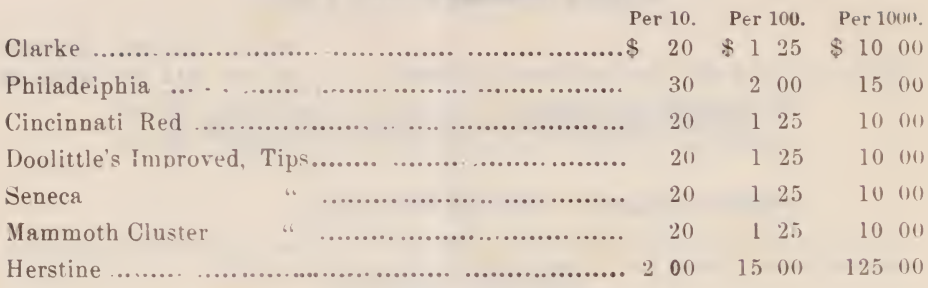

\section{$B \perp A C K B E R R I E S$.}

Kittatinny

Crystal White

\section{CURRANTS.}

\begin{tabular}{|c|c|c|c|c|c|c|c|c|}
\hline Sherry, & & ars, & No. 1 & $1, \ldots \ldots \ldots \ldots \ldots \ldots \ldots \ldots$ & 50 & & & 35 \\
\hline " & 2 & ." & " 2 & $2 \ldots \ldots$ & 40 & 3 & 50 & 30 \\
\hline La Versaillaise, & 2 & " & .. & $1 \ldots \ldots \ldots \ldots \ldots \ldots \ldots \ldots \ldots \ldots \ldots \ldots \ldots \ldots$ & 50 & 4 & 00 & 35 \\
\hline$"$ " & 2 & " & " 2 & $2 \ldots \ldots \ldots \ldots \ldots \ldots \ldots \ldots$ & 40 & 3 & 51) & 30 \\
\hline ertile d Angers, & 2 & " & . 1 & $1 \quad \ldots \ldots \ldots \ldots \ldots \cdot \cdots \cdots$ & 50 & 4 & 00 & 35 \\
\hline " & 2 & . & " 2 & 2 . & 40 & 3 & 50 & 30 \\
\hline bite Grape, & 2 & ." & . 1 & $1, \ldots \ldots \ldots \ldots \ldots \ldots \ldots \ldots \ldots$ & 50 & 4 & 09 & 35 \\
\hline *. & 2 & " & " 2 & $2 \ldots \ldots \ldots \ldots \ldots \ldots \ldots \ldots \ldots$ & 40 & 3 & 50 & 30 \\
\hline hite Dutch, & 2 & ." & " 1 & $1 \quad \ldots \ldots \ldots \ldots \ldots \ldots \ldots \ldots \ldots$ & 50 & 4 & 00 & 35 \\
\hline .. & & .6 & . 2 & $2 \ldots \ldots \quad . . \quad \therefore \ldots \ldots \ldots \ldots \ldots \ldots$ & 40 & 3 & 50 & 30 \\
\hline ed Dutch, & & .. & . 1 & $1 \ldots \ldots \ldots \ldots \ldots \ldots \ldots \ldots$ & 40 & 3 & 50 & 30 \\
\hline$" \quad$ " & 2 & " & " 2 & $2 \ldots \ldots \ldots \ldots \ldots \ldots \ldots \ldots \ldots \ldots \ldots \ldots \ldots \ldots$ & 40 & 3 & 00 & 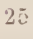 \\
\hline ire des Sal & & & & • & b0 & 5 & & \\
\hline
\end{tabular}

\section{GOOSEBERRIES.}

Houghton s Seedling, 2 years, fine.... ............ 50

\section{STRAW BERRIES.}

Chas. Downing, Downer s Prolific, Green Prolific, $25,50 \quad 100+00$ Burr's New Pine, Kentucky...................... " $50 \quad 100+00$ Wilson's Albany 敬 $10,000, \$ 40 \quad 00 \quad 50$ i $00 \quad 500$

\section{RHUBARB.}

Myatt's Linn:eus, strong 2 rear plants 


\section{SEEDLINGS AND STOCKS.}

Pear Seedlings, 1 year, extra

Per 1000. Per 10,00n.

Horse Plum Seedlings, 1 year, No. 1....................... 15 $150 \quad 12500$

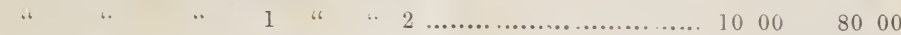

Cherry, Mahaleb, imported in Spring, No. 1................ $1600 \quad 15000$

Peach Seedlings, for grafting............................. $500 \quad+500$

" $\quad$ " $\quad$ "t transplanting......................... $400 \quad 3500$

Calycanthus Seedlings, 6 to 8 inches............per 100, $\$ 400 \quad 3000$

\section{ROOT GRAFTS.}

We have conc'uded to discontinue the practice of putting up Root Grafts, and advise instead that those who intend planting new nurseries, should make such grafts for themselves. To those who have had no experience in this kind of work, we will send samples of Root Grafts, showing style of workmanship, on receipt of twenty-five cents. We will be glad to supply the seedlings and scions needed to make the number of grafts desired.

\section{SEEDS.}

Apple, prime and fresh, (40 lbs. to the bushel).......\$ $\$ \$$ Per 10 bush. Per lb. Per bush.
Pear, $\quad$ ". frosted, ready to plant. .......

Horse Plum Pits

7500

800

These Plum Pite are in perfect condition for planting, having been stratified very early. Many are already bursted.

\section{BUDS.}

\begin{tabular}{|c|c|c|}
\hline Per & Per 100. & Per 1000 \\
\hline pple ........ & $\$ 50$ & $\$ 200$ \\
\hline berry.............................................25 & 50 & 3 \\
\hline 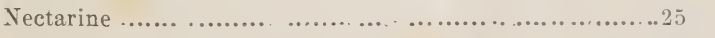 & 50 & 3 \\
\hline 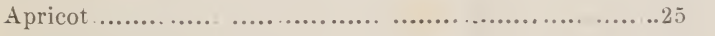 & 50 & 3 \\
\hline , Standard. ..........................................25 & 50 & 1 \\
\hline “ Gulden Dwarf......................................5 50 & 5 & 3 \\
\hline 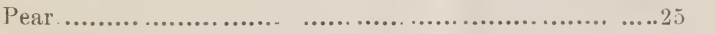 & 0 & 3 \\
\hline$\ldots .25$ & 50 & 3 \\
\hline$\ldots 50$ & 100 & 6 \\
\hline
\end{tabular}

When liss than five hundred of a variety are ordered, huds will be charged at the rates per hundred: when less than one hundred, at the rates per ten. 


\section{HEDGE PLANTS.}

Per 10n. Per 10(0), Per 10,8(t) Per 50,000 Osage Orange, 1 year, fine. ................50c. \$2 \$0 \$2 \$0 $\$ 00 \quad \$ 90 \quad 00$

These plants are "heeled in" in the cellar, and show no signs of exposure to th.. winter or damage from . ther canses, as is often the case wirh Usage. Both roots and tops are in perfect condition.

\section{MISCELLANEOUS.}

Dibbles, the best in use for planting grafts, etc......................each $\$ 125$ Bass Bark, for budding .... ......................per lb. 50c., per 10 lbs 300 Labels, plaiu tree ......................... per $1000,75 \mathrm{c}$, per 10.060 , 600 Wire tur Labels, cut ...................................... . . Budding Knives .................................................each 100

\section{CHEAP LIST.}

The plants off red under this head are for the most part such as are left standing in the nurseries ufter takilig up the heavier sizes. This class of plauts is valuable for trausplant ing inte uursery rows, and specially so t r thos. unt fumiliar with the process of graftiug, budding and the care of young plauts Thumgh his list decided pecuniary arlyantages waty be found to orcharcists willug th gire the nfcessary attention required in th care of small trees and plants. It is also well calculated to neet the wants of those raquiring very distant shipments In Apples, the best Northern and Southern sorts can be supplied.

Per 10. Per 100. Per luno.

Apples 3 and 4 years. 4 to $5 \mathrm{ft}$., imperfectly shaped.....\$1 on $\$ 400 \quad \$ 30$ no

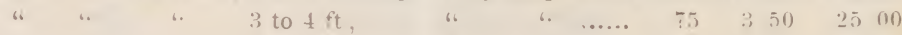

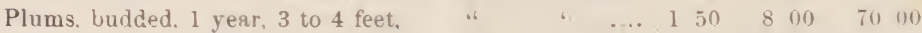

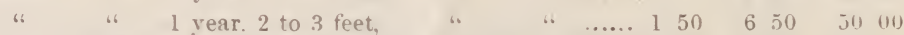

"6 Grafted, Wild Goose, 1 year. 2 to 3 feet, light .... $150 \quad 1250$

Currants, Cherry and White Dutch, 2d size. 2 years..... $100 \quad 300$

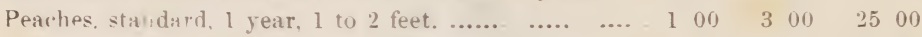

Guostberries. Houghton, 2 years, $2 \mathrm{~d}$ size.................. 1 $00 \quad 300 \quad 2500$ 


\section{ORNANENTAL DEPARTIENT.}

\section{DECIDUOUS TREES.}

Apple, Double Flowering, in variety, three sears old..\$2 00

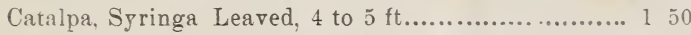

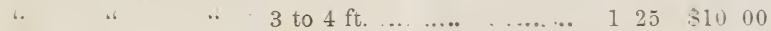

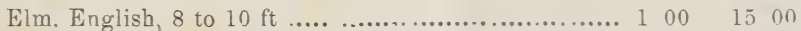

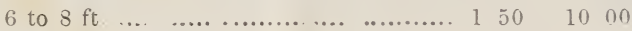

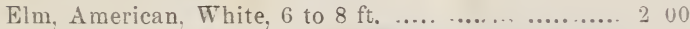

Kolreuteria Paniculata, 2 to $3 \mathrm{ft} . \ldots \ldots \ldots . . . . . . \ldots \ldots . . .250$

Laburnum, or Golden Chain, 3 to $4 \mathrm{ft} \ldots \ldots \ldots \ldots \ldots \ldots . \ldots 200$

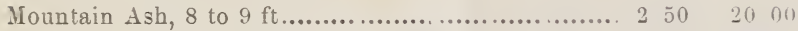

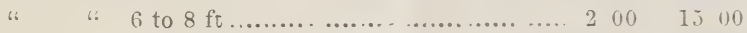

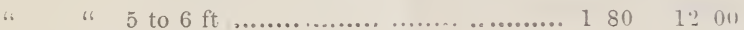

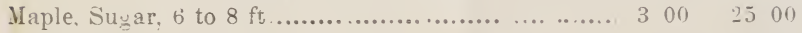

Silver. 6 to $8 \mathrm{ft}$............................ $100 \quad 800$

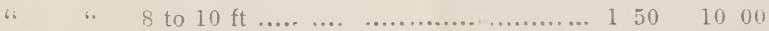

Mountain Ash. Oak-]eared. ......................... 300

Peach, Blood-leared, $3 \frac{1}{2}$ to $4 \mathrm{ft} \ldots \ldots \ldots$.... each 35 cts. $250 \quad 2000$

Peach, Double Flowering, five sorts................ $200 \quad 1500$

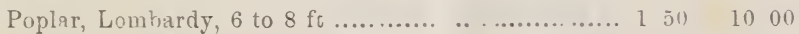

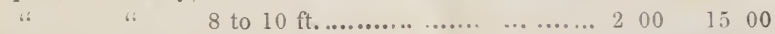

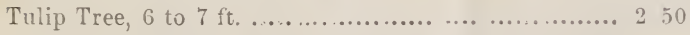

\section{WEEPING DECIDUOUS TREES.}

Ash. Weeping Mountain, ......................... 5 00

Willow, " New American......................... 600

" " Kilmarnock.............................6 $600 \quad 5500$ 


\section{DECIDUOUS ORNAMENTAL SHRUBS.}

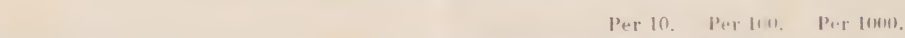

Althea, best double varieties. 2 to 3 feet $\$ 500$ $\$$

common 2 to 3 feet ........................ 150

(1) (])

Berberry, purple, 2 to $: 3$ feet ..................... . 2 00

Calycanthus, 12 to 18 inches, one year secdlings..... 100 " 6 to 8 inches, one rear stedlings..........

Forsythia, Virdissima. ........................... 2 50

Fortunii new ................................. 300

Lilac, common, purple. and white ................. ? 50

.6 Josikea, new ............................. 3

Purple Fringe, Mist or fimoke Tree, 2103 feet...... 2 (1)

Quince, Japan, 2 jears, 1 to 2 teet .................. 2 50

Snow Bail, 2 to 3 feet ............................ 1 it

Ápireas, best varieties ..........................

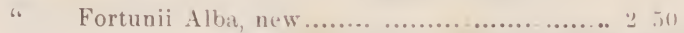

.. Thunbergia, new. ......................... 5011

Tamarix, Africana .... .......................... 2 511

Weigelia, Rosea................................. 2 50

White Fringe ..... . ........................... 3010

\section{VINES AND CREEPERS.}

American Ivy, or V'irginia Creeper. ........... . $150 \quad$ j 00

Clematis, Viticella, Cerulea, Flammula, Sophia ..... 350

" Jackmanii, standishii................. . $\tau_{j}$

Bignonia Radicans .............................. 1 $; 0$

Cissus, Variegated .......................... .... 2 ju

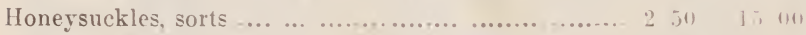

Wisteria, Magnifica.................................. 2 (g) 1500

sinensis............................... 2 001015111

\section{EVERGREEN TREES.}

Arbor Vitit, American, 1 foot. ......................... $x^{\prime \prime}$

" $\quad$ ". 3 feet. ...................... 2 50.20 ur

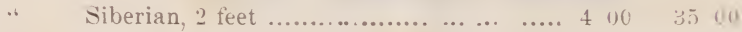

.. Golden, 2 feet........................... 750

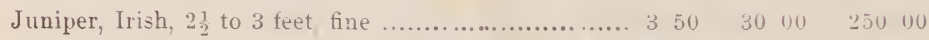

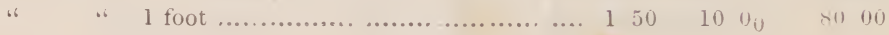




\section{EVERGREEN TREES-Continued.}

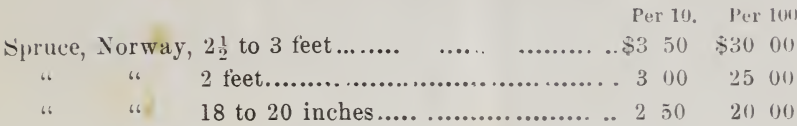

\section{ROSES.}

Hybrid, Perpetual... ................................. 2 $50 \quad 20$ (0)

Climbing.......................................... $200 \quad 1500$

Moss ................................................. $300 \quad 2500$ 
